\title{
Reproductive biology of a viviparous lizard (Mabuya dorsivittata) from the subtropical Wet Chaco of Argentina: geographical variations in response to local environmental pressures
}

\author{
MARTÍN A. ORTIZ ${ }^{1}$, JORGELINA M. BORETTO² and NORA R. IBARGÜENGOYTÍA ${ }^{2}$
}

\author{
${ }^{1}$ Laboratorio de Herpetología, Facultad de Ciencias Exacta y Naturales y Agrimensura, \\ Universidad Nacional del Nordeste, Av. Libertad, 5470, 3400 Corrientes, Argentina \\ ${ }^{2}$ Instituto de Investigaciones en Biodiversidad y Medioambiente/INIBIOMA, Consejo Nacional de Investigaciones Científicas \\ y Técnicas/CONICET, Universidad Nacional del Comahue, San Carlos de Bariloche, 8400 Río Negro, Argentina
}

Manuscript received on October 13, 2017; accepted for publication on April 17, 2018

\begin{abstract}
How to cite: ORTIZ MA, BORETTO JM AND IBARGÜENGOYTÍA NR. 2019. Reproductive biology of a viviparous lizard (Mabuya dorsivittata) from the subtropical Wet Chaco of Argentina: geographical variations in response to local environmental pressures. An Acad Bras Cienc 91: e20170817. DOI 10.1590/0001-3765201920170817.
\end{abstract}

\begin{abstract}
Herein we studied the reproductive biology of a viviparous lizard (Mabuya dorsivittata) from the Wet Chaco region (northeastern Argentina) and compared the results with other populations from the Espinal (central Argentina) and the Atlantic Forest (southeastern Brazil), and with other Neotropical species of Mabuya to better understand the possible causes of its reproductive phenotype variation. Males and females of M. dorsivittata from the Wet Chaco exhibited associated, seasonal, and annual reproductive cycles. Spermatogenic activity related positively to a lengthening photoperiod reaching maximum activity in late spring (December). Females displayed an extended gestation period of 11 months, from midsummer (February) to late spring or early summer (December) when births occur. Embryonic development was associated with temperature and historical rainfall. Litter size ranged from 3 to 8 (mean $=5.3 \pm 1.3$ SD) and increased with body size and body mass of females. Fat-body mass varied seasonally and was inversely correlated with spermatogenesis and to embryonic development. Females were larger in body size and interlimb length, and smaller in head length than males. We observed interpopulational differences in minimum body size, litter size, and timing of birth, probably as a result of phenotypic plasticity, genetic divergence or both.
\end{abstract}

Key words: reproductive cycle, sexual dimorphism, ecotypic variation, lizard, Squamata.

\section{INTRODUCTION}

Different environmental conditions can lead to variation in life history traits such as age and size at sexual maturity, maximum body size, fecundity, reproductive timing, and lifespan among individuals, populations, and species, as the result

Correspondence to: Jorgelina Mariela Boretto

E-mail: borettojm@comahue-conicet.gob.ar ORCid: https://orcid.org/0000-0002-3531-0442 of phenotypic plasticity, genetic divergence or both (Dunham et al. 1988, Wapstra and Swain 2001, Radder 2006). Geographical variations in life history traits correspond to gradients of environmental factors such as temperature, photoperiod, food availability, predation, and competition (Adolph and Porter 1993, Seigel and Ford 2001, Zeng et al. 2013). The comparative study of populations provides information to identify the possible causes 
of variation, and their ecological and adaptive value (Radder 2006).

In this sense, temperate montane environments with cool temperatures, short growing seasons, and summer rainfall, play a role in the evolution of a suite of reproductive characteristics shared by evolutionarily distant viviparous lizard species inhabiting these harsh climates (Shine 1985, Ramírez-Bautista et al. 1998, 2002). Nevertheless, the genus Mabuya Fitzinger, 1826, characterized by a highly specialized placentotrophic viviparity (Vitt and Blackburn 1983, 1991, Jerez and RamírezPinilla 2001, 2003, Blackburn and Vitt 1992, 2002, Leal and Ramírez-Pinilla 2008), inhabits tropical and subtropical latitudes, so it is a particularly interesting group for reproductive studies because it contrasts with the "cold climate" hypothesis proposed to explain the origin of viviparity in Squamata (Shine 1985). The hypothesis of maternal manipulation of thermal conditions for embryogenesis offers an explanation for viviparous squamates species living in tropical zones (Webb et al. 2006). According to this hypothesis, pregnant females prefer a range of body temperatures different from non-pregnant females and adjust their body temperature producing offspring phenotypes that enhance their fitness (Webb et al. 2006, Ji et al. 2007, Rodríguez-Díaz and Braña 2011).

Mabuya belong to the Scincidae family, with 26 species (Jerez 2012) distributed in tropical and subtropical environments of South America (Mausfeld et al. 2002). Placentotrophy is considered by Mausfeld et al. (2002) to be one of the synapomorphies of the South American Mabuya species, and represents a strong convergence with eutherian mammals (Blackburn 1992). The Scincidae family and the genus Mabuya have been the focus of recent taxonomic reviews. Hedges and Conn (2012) proposed to elevate the subfamilies Acontiinae, Egerniinae, Eugongylinae, Lygosominae, Mabuyinae, Scincinae and Sphenomorphinae to the family level, whereas
Pyron et al. (2013) argued that Scincidae family is a monophyletic clade and concluded that the degree of divergence among the various scincid subfamilies is insufficient to justify elevating them to the family level. Here, we follow Pyron et al. (2013) in restricting the genus Mabuya to a monophyletic clade of Neotropical species of Scincidae, an interpretation supported by multiple phylogenetic analyses and several morphological synapomorphies (Mausfeld et al. 2002, Whiting et al. 2006, Miralles and Carranza 2010).

Despite the broad distribution of genus Mabuya in South America, the reproductive biology has been studied mainly in the Amazon biomes (M. nigropunctata [= M. bistriata], Vitt and Blackburn 1991; M. mabouya, Duellman 1978; Dixon and Soini 1986) and in the Brazilian biomes, the latter including the Atlantic Forest, (M. frenata, Vrcibradic and Rocha 1998; M. macrorhyncha and M. agilis, Rocha and Vrcibradic 1999), the Cerrado (M. frenata, Vitt 1991, Pinto 1999; M. nigropunctata, Pinto 1999; M. guaporicola, Mesquita et al. 2000), and the Caatinga (M. agilis [= M. heathi], Vitt and Blackburn 1983; M. arajara, Ribeiro et al. 2015). These studies have described a seasonal reproductive cycle in both sexes, with a unimodal pattern of births. However, in a Colombian population from the tropical wet forest (M. mabouya, Ramírez-Pinilla et al. 2002), males and females exhibited a continuous reproductive cycle, with a bimodal pattern of births.

The species Mabuya dorsivittata (Cope, 1862) is distributed across Bolivia, Paraguay, Brazil, Uruguay and Argentina, occupying a variety of habitats including grasslands, forests and rocky outcrops (Cei 1993, Vrcibradic et al. 2004, Aun et al. 2011, Williams and Kacoliris 2011, Núñez 2012). The reproductive cycle has been studied in the Espinal biome of Argentina and is characterized by a seasonal reproductive pattern (Aun et al. 2011). Litter sizes in southeastern Brazil were reported by Vrcibradic et al. (2004), but no information exists 
on Mabuya from the subtropical Wet Chaco region, which is one of the largest South American biomes with the greatest herpetofaunal diversity (Alvarez et al. 2002). In the present study of $M$. dorsivittata, we describe the male and female reproductive cycles, the fat-body cycle and the extent of sexual dimorphism for a subtropical population from the Wet Chaco, and the results are compared among populations and congeneric species to understand the possible causes of the reproductive phenotype and its relationship with the environment they inhabit.

\section{MATERIALS AND METHODS}

\section{STUDY AREA AND CLIMATE}

Mabuya dorsivittata was studied in the grasslands of Corrientes Province (Argentina), part of the Eastern District of the Chaco Phytogeographic Province known as Wet Chaco (Cabrera and Willink 1973, Cabrera 1976, Carnevali 1994), belonging to the South American Chaco region an area of approximately $200.000 \mathrm{~km}^{2}$ (Cabrera 1976, Ginzburg and Adámoli 2006). The climate in Corrientes Province is mainly warm and subtropical; there is no dry season although winter rainfall is significantly lower (Cabrera 1976, Bruniard 1997), and the average annual rainfall varies from 1000 to $1500 \mathrm{~mm}$. Mean annual temperatures varies from 20-22 ${ }^{\circ} \mathrm{C}$. Mean maximum temperatures occur in January $\left(26-28^{\circ} \mathrm{C}\right)$, while the mean minimum temperatures are recorded in July $\left(13-16^{\circ} \mathrm{C}\right)$; frosts are uncommon (Cabrera 1976, Carnevali 1994, Bruniard 1997).

Historical records of mean temperature, photoperiod and rainfall from 1990 to 2010 and during the sampling period from 2011 to 2013 were provided by the Servicio Meteorológico Nacional and the Servicio de Hidrografía Naval Argentino (Figure 1). During 2011 and 2012 a La Niña climatic event occurred, characterized by particular patterns of temperature and rainfall, which alter seasonal climate conditions. Consequently, we also include historical data from 1990 to 2010 to discuss the results of the present study.

\section{SAMPLING AND LABORATORY METHODS}

Most specimens ( $\mathrm{n}=36$; 13 adult males; 2 juvenile males, 18 adult females and 3 juvenile females) were collected from September 2011 to May 2013 in San Cayetano (2733'22” S, 58 40’33”'W), Capital Department, Corrientes Province by hand, driftfences with pitfall traps, or by using artificial shelters. We completed the sample with two additional adult females from the herpetological collection of the UNNE of Corrientes (UNNEC: 10574, 10586) collected in October 2009 in the localities Paraje Loma Alta, Concepción Department (28²5'21" S, 57 56'57' W) and Paraje Maloyas, San Luis del Palmar Department $\left(27^{\circ} 42^{\prime} 37^{\prime}\right.$ S S, 58 $\left.09^{\prime} 40^{\prime \prime} \mathrm{W}\right)$ from environments similar to those in Corrientes Province. Specimens collected in 2011-2013 were euthanized by intraperitoneal administration of anesthesia (carticaine L-adrenaline), following the recommendation of the European Commission (Close et al. 1997), and the ASIH/HL/SSAR Guidelines for the Use of Live Amphibians and Reptiles as well as the regulations detailed in Argentinean National Law \#14346.

The specimens were fixed in Bouin's solution for 24 hours, stored in 70\% ethanol and deposited at the herpetological collection of the Universidad Nacional del Nordeste (UNNEC), Corrientes province. Prior to fixation, lizards were sexed and weighed (body mass, BM) to the nearest $0.01 \mathrm{~g}$ with a digital balance (Ohaus ${ }^{\circledR}$ traveler scale TA320) and measured using a digital caliper (Essex ${ }^{\circledR}, 0.01$ $\mathrm{mm}$ ) to $0.1 \mathrm{~mm}$. Fat bodies were excised after the necropsy of each adult lizard and weighed to nearest $0.01 \mathrm{~g}$ with a digital balance. Sexual dimorphism was described sensu Boretto et al. (2007) and Boretto and Ibargüengoytía (2009). The following variables were measured using a digital caliper: 

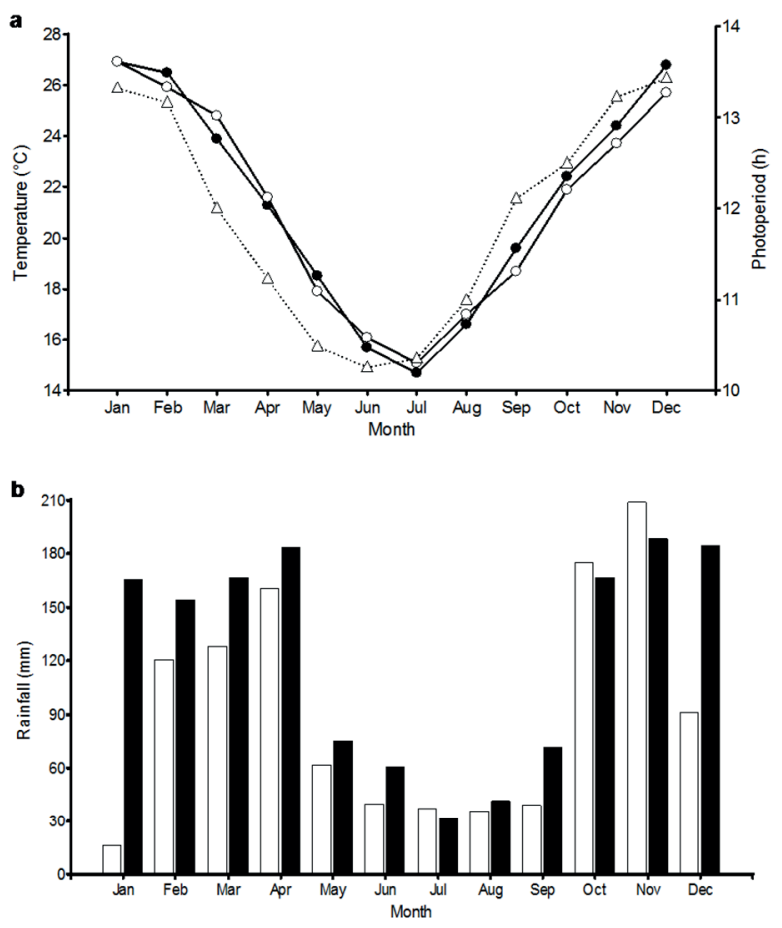

Figure 1 - Monthly means of climatic variables in Corrientes, Argentina. (a) Temperature from 2011 to 2013 (solid circles), historical temperature from 1990 to 2010 (open circles) and photoperiod (triangles). (b) Rainfall from 2011 to 2013 (white bars) and historical rainfall from 1990 to 2010 (black bars). Climatic data were obtained from the Servicio Meteorológico Nacional and Servicio de Hidrografía Naval Argentino.

snout-vent length (SVL), head length (HL), head width (HW) and head height $(\mathrm{HH})$ at interparietalscale level, neck width (NW), distance between front and hind limbs (Interlimb length, IL; sensu Olsson et al. 2002), diameter of the front leg (FLD) and hind leg (HLD) at the insertion to the shoulders and pelvic girdles respectively, hip width (HipW), measured as the body width at the insertion of hind legs, maximum body width (BW), tail width immediately posterior to vent (TWV), and status of the tail (ST; intact, cut or regenerated).

\section{MALE REPRODUCTIVE CYCLE}

The male gonadal cycle was determined based on macro- and microscopic observations. Testes size (TS) was measured as an antero-posterior diameter using a digital caliper $( \pm 0.1 \mathrm{~mm})$. Gonads were dehydrated in an ethanol series and embedded in paraffin for 24 hours at $52{ }^{\circ} \mathrm{C}$. Following a conventional histological protocol (Humason 1979), 5- $\mu \mathrm{m}$ sections were cut with a rotary microtome $\left(\right.$ Arcano $\left.^{\circledR}\right)$ and stained with hematoxylin and eosin.

Spermatogenic stages were determined by the most advanced cell type present in the seminiferous tubules following Mayhew and Wright (1970), and cell types were recognized based on Gribbins (2011). Five spermatogenic stages were defined: (I) only spermatogonia, (II) primary and secondary spermatocytes, (III) spermatozoa in the seminiferous tubules, (IV) early regression with cellular debris and scarce spermatozoa in tubular lumen, and (V) complete regression, characterized by no cell division and no lumen (modified from Mayhew and Wright 1970). The presence or absence of spermatozoa in the epididymes and/ or ductus deferens was also registered. Minimum SVL at sexual maturity in males was determined by the shortest specimen with spermatogenic activity (stages II-V) or spermatozoa in the epididymes or ductus deferens.

\section{FEMALE REPRODUCTIVE CYCLE}

The female reproductive cycle was defined based on macroscopic and microscopic observations of the reproductive tract and the presence and number of oviductal embryos and corpora lutea. Pregnant females were classified (sensu Leyton et al. 1980) based on embryonic development as initial (from cleavage to somatic embryos), medium(from curvate trunk to elongated limbs with 5 fused fingers), and advanced (fetus with scales and pigmented skin). Embryos from left oviduct were used to estimate the embryos size based on the diameter taken as the distance across the chorionic vesicle (Vitt and Blackburn 1991). Embryos were observed with a stereoscopic microscope (Olympus ${ }^{\circledR}$ SZH10/ 
AB3639, Tokyo, Japan) and measured through digital images using an Image-Pro Plus analyzer (Media Cybernetics, Inc., Rockville, MD, USA). Litter size was determined by counting the number of embryos in uterus (Ibargüengoytía and Cussac 1998). Minimum SVL at sexual maturity of females was estimated considering the shortest female with embryos in uterus or corpora lutea. Female with oviducts without folds or presence of small folds were classified as juveniles, following the definition of Ibargüengoytía and Cussac (1998).

\section{STATISTICAL ANALYSES}

Statistical analyses were conducted using INFOSTAT (version 2011), SPSS (version 17.0), and SIGMAPLOT (version 10.0). Assumptions of normality and homogeneity of variance were tested with the Shapiro-Wilk test and Levene's test, respectively. Dependence between variables was tested performing simple regression, Pearson and Spearman correlations. When correlation between independent variables and SVL was found, residuals of linear regression were used to perform further analysis (Ramírez-Bautista and Vitt 1997).

To analyze sexual dimorphism in mean SVL, we used a t-test. All morphometric variables (BM, HL, HW, HH, NW, IL, FLD, HLD, HipW, BW, and TWV) were ln-transformed and then regressed against ln-transformed SVL. The residuals of these regressions were used in the Stepwise discriminant analysis (based on p-value with $\alpha=0.05$ and $\alpha$ $=0.10$ as input and output significance levels) to determine the variables that better explain the differences between the sexes. In order to determine the possible causes of intersexual differences in the frequency of caudal autotomy, a $\chi^{2}$ test was performed to compare intact versus broken or regenerated tails between males and females. The significance level used was $\mathrm{p}<0.05$ for all statistical tests and results are presented as means \pm standard deviation (SD).

\section{RESULTS}

\section{ANNUAL ACTIVITY, BODY SIZES AND SEXUAL DIMORPHISM}

Adult males and females were captured through the year (Figure 2), whereas juveniles were captured only from mid-summer (February) to early winter (July). The smallest SVL of any lizard was recorded in February. The minimum adult size for males was $51.2 \mathrm{~mm} \mathrm{SVL}$, corresponding to a specimen with spermatocytes in the seminiferous tubules (stage II). In females, the minimum adult size was 49.0 $\mathrm{mm}$ SVL, corresponding to a gravid specimen with embryos in initial stage of development. The SVL of adult males ranged from 51.2 to $70.9 \mathrm{~mm}$ (mean $=60.7 \pm 6.4, \mathrm{n}=13)$, and the BM from 2.32 to 5.25 $\mathrm{g}($ mean $=3.54 \pm 0.85 \mathrm{~g}, \mathrm{n}=12)$. Adult females ranged from 49.0 to $82.4 \mathrm{~mm} \mathrm{SVL} \mathrm{(mean}=67.0 \pm$ $9.0, \mathrm{n}=20)$, and 1.25 to $9.32 \mathrm{~g} \mathrm{BM}($ mean $=5.17 \pm$ $2.18 \mathrm{~g}, \mathrm{n}=20$ ). Male and female juveniles ranged from 42.2 to $52.6 \mathrm{~mm} \mathrm{SVL} \mathrm{(mean}=48.3 \pm 4.45, \mathrm{n}$ $=5$ ), and from 0.97 to $2.70 \mathrm{~g} \mathrm{BM}($ mean $=1.93 \pm$ $0.76, \mathrm{n}=5)$.

Adult females exhibited larger body size (SVL; $\mathrm{T}=-2.10, \mathrm{p}=0.043, \mathrm{n}=33$; Figure 3) and larger interlimb length than adult males, while males showed larger heads (discriminant analysis; $\lambda=$ 0.502, $\chi^{2}=19.99, \mathrm{df}=2, \mathrm{p}<0.001, \mathrm{n}=33$ ). Adult males and females did not differ in the frequency of

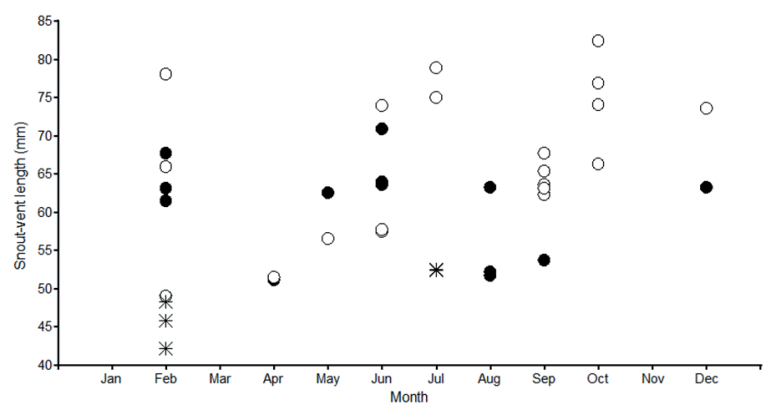

Figure 2 - Snout-vent length distribution by month in Mabuya dorsivittata. Adult males (solid circles), adult females (open circles), juveniles (asterisks). 
caudal autotomy $\left(\chi^{2}=0.53, \mathrm{df}=1, \mathrm{p}=0.466, \mathrm{n}=\right.$ $33)$. Broken and regenerated tails were recorded in $77 \%$ of males (10 of 13 individuals) and in $65 \%$ of females (13 of 20 individuals). Males and females with intact tails were not different in snout-vent length or body mass from those with broken or regenerated tails $\left(\mathrm{SVL}_{\text {males}}, \mathrm{T}=-1.72, \mathrm{p}=0.113\right.$; $\mathrm{BM}_{\text {males}}, \mathrm{T}=-0.95, \mathrm{p}=0.367 ; \mathrm{SVL}_{\text {females }}, \mathrm{T}=-0.60$, $\mathrm{p}=0.556 ; \mathrm{BM}_{\text {females }}, \mathrm{T}=-0.45, \mathrm{p}=0.661$ ).

\section{MALE REPRODUCTIVE CYCLE}

The relationship between male SVL and testicular size was positive (Linear Regression; $\mathrm{r}^{2}=0.47, \mathrm{~F}_{1,11}=$ $9.67, \mathrm{p}=0.009, \mathrm{n}=13$ ); therefore, residual testicular size (TS) was used for the following analyses. The smallest TS values were observed in late autumn (June), and increased gradually in mid-winter (August) until late spring when the TS reached the highest value (December; Figure 4a). The TS was positively correlated with the photoperiod (Spearman correlation, $r_{s}=0.57, p=0.04$ ), but not with temperature or rainfall (temperature ${ }_{(2011-2013)} ; r_{s}$ $=0.16, \mathrm{p}=0.61$; historical temperature ${ }_{(1990-2010)} ; \mathrm{r}_{\mathrm{s}}=$ $0.39, \mathrm{p}=0.19 ; \operatorname{rainfall}_{(2011-2013)} ; \mathrm{r}_{\mathrm{s}}=-0.02, \mathrm{p}=0.94$; historical rainfall $\left.{ }_{(1990-2010)} ; r_{s}=0.18, p=0.56\right)$.

The histological study of gonads revealed that juvenile males with spermatogonia in testes (stage I, $\mathrm{n}=2$ ) occurred in winter (July; Figure 5), whereas adult males with primary and secondary spermatocytes (stage II, $n=4$ ) were captured from early autumn (April) to early spring (September), and those with spermatozoa in the seminiferous tubules (stage IV, $\mathrm{n}=3$ ) were found in summer (December and February). Males with early testicular regression (stage $\mathrm{V}, \mathrm{n}=2$ ) were captured from mid-summer (February) to late autumn (June), and males with complete regression (stage VI, $n=4$ ) were found between mid-autumn (May) and mid-winter (August). In addition, sperm in the epididymis was recorded only in males with testes in stage IV.
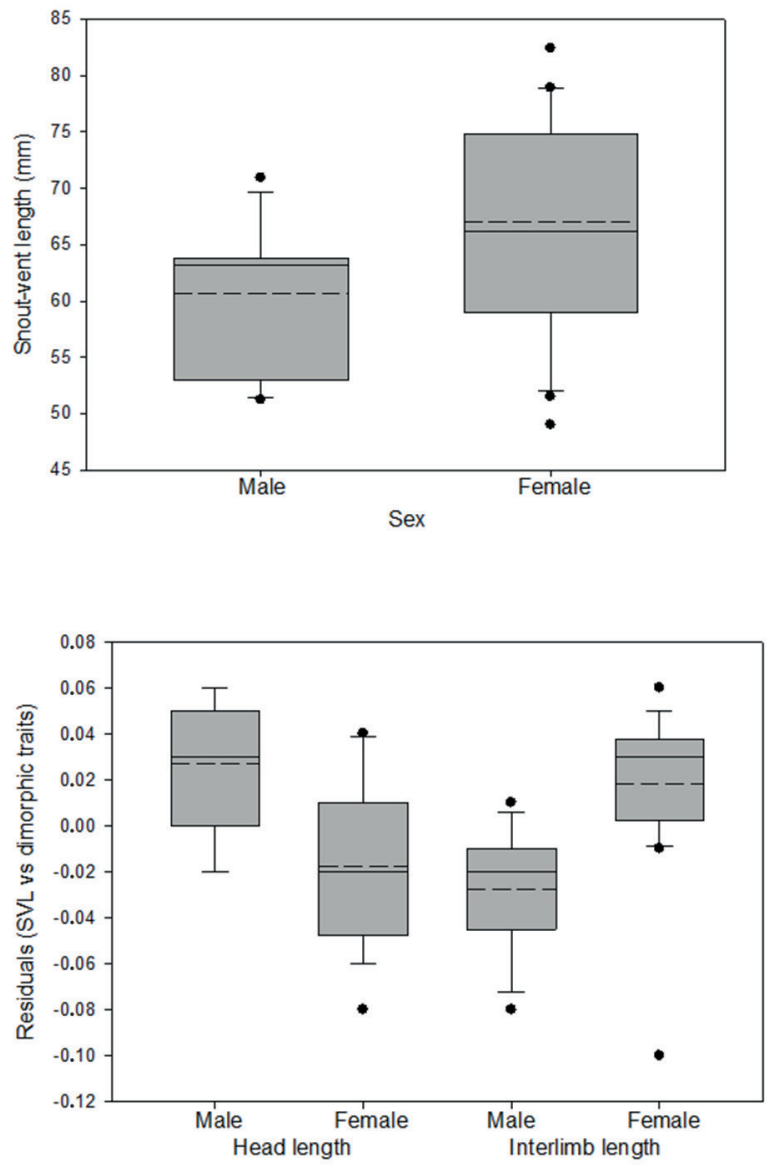

Figure 3 - Box plot of the significant dimorphic traits $(\mathrm{p}<$ 0.05 ) of female and male Mabuya dorsivittata. Median (black horizontal line), mean (dashed line), whiskers $\left(10^{\text {th }}\right.$ and $90^{\text {th }}$ percentiles) and outliers (solid circles) are indicated.

\section{FEMALE REPRODUCTIVE CYCLE, EMBRYONIC DEVELOPMENT AND LITTER SIZE}

Gravid females $(n=20)$ were observed from midsummer (February) to late spring (December), showing a progressive advance in the embryonic development (Figure 4b). Gravid females collected in mid-summer (February) showed embryos with evidence of initial developmental stages and small chorionic vesicles (largest diameter of the chorionic vesicle $=1.3 \mathrm{~mm}, \mathrm{n}=3$ ). Very little embryonic growth occurred between February and October, followed by fast growth from October to December (Figure 4b). From midsummer (February) until late winter (September) 

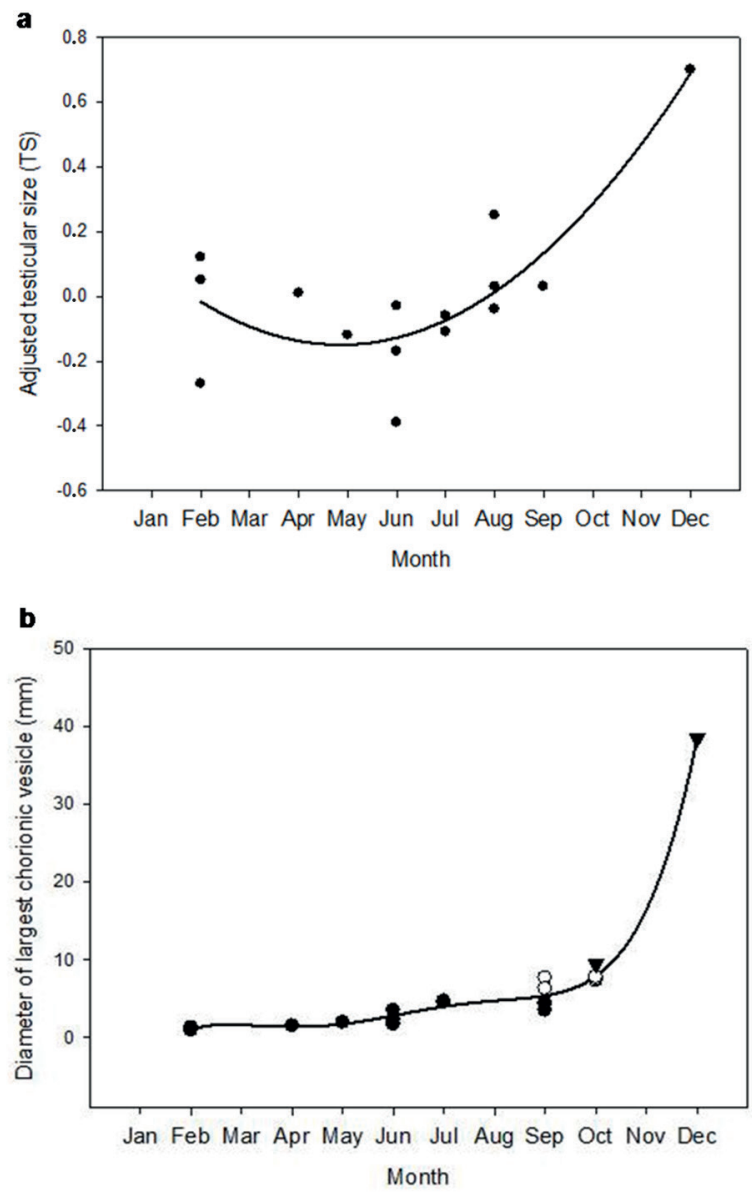

Figure 4 - Reproductive cycle of Mabuya dorsivittata. (a) Variation in adjusted testicular size of adult males throughout the year. Solid circles correspond to the residuals from snout-vent length versus testicular diameter regression. (b) Variation of size of the largest chorionic vesicle of different embryonic stage: initial (solid circles), medium (white circles) and advance (triangles). Lines show change in testicular and chorionic vesicle size corresponding to a second and fifth order polynomial equation respectively.

females exhibited initial embryonic developmental stage $(n=13)$. Females with medium embryonic developmental stage $(n=5)$ were found from late winter (September) to early spring (October), while females with advanced embryonic developmental stage $(n=2)$ were captured in spring (October and December). During October one female showed embryos in an advanced stage of development, with fingers completely separated, but the skin not yet pigmented. However, another female with

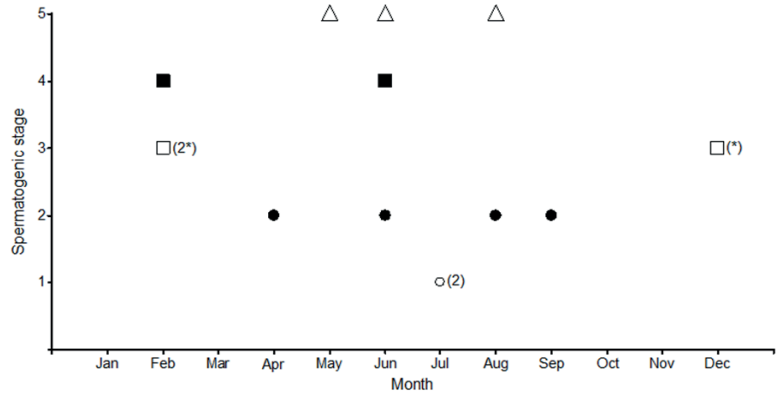

Figure 5 - Male reproductive cycle of Mabuya dorsivittata. Spermatogenic stage: (1) only spermatogonia (white circles); (2) primary and secondary spermatocytes (black circles); (3) spermatozoa in the tubule (white squares); (4) early regression with cellular debris and scarce spermatozoa in tubular lumen (black squares); and (5) complete regression, characterized by no cell division and no lumen (white triangles). Asterisks indicate presence of spermatozoa in the epididymis. The values in brackets are the number of observations; no value shown indicates a single observation.

near-term embryos was collected on December 7 (embryos with scales and skin completely pigmented), suggesting that parturition occurs during December. Litter size varied from 3 to 8 offspring (mean $=5.3 \pm 1.3, \mathrm{n}=20)$ and increases with SVL (Pearson Correlation; $r=0.66, p=0.002$, $\mathrm{n}=20)$ and body mass $(\mathrm{r}=0.46, \mathrm{p}=0.04, \mathrm{n}=20)$. Embryonic development was positively correlated with monthly mean temperature ${ }_{(2011-2013)}$ (Spearman Correlation; $\left.r_{s}=0.53, p=0.023\right)$, and historical rainfall $_{(1990-2010)}\left(\mathrm{r}_{\mathrm{s}}=0.47, \mathrm{p}=0.049\right)$, but not with photoperiod $\left(r_{s}=0.46, p=0.057\right)$, rainfall $_{(2011-2013)}(r$ $=0.10, \mathrm{p}=0.705)$ or historical temperature ${ }_{(1990-2010)}$ $(\mathrm{r}=0.33, \mathrm{p}=0.181)$.

\section{FAT-BODY CYCLES}

Fat-body mass was correlated with SVL of adult males and females (Linear Regression; $\mathrm{r}^{2}=0.14$, $\mathrm{p}=0.033, \mathrm{n}=33$ ). The adjusted fat-body mass of males showed a negative correlation with TS (Spearman Correlation; $\mathrm{r}_{\mathrm{s}}=-0.57, \mathrm{p}=0.04, \mathrm{n}=$ 13; Figure 6a). Similarly, in females we found a negative correlation between the adjusted fat-body mass and the embryonic development $\left(r_{s}=-0.67, p\right.$ $=0.001, \mathrm{n}=20$; Figure 6b). 

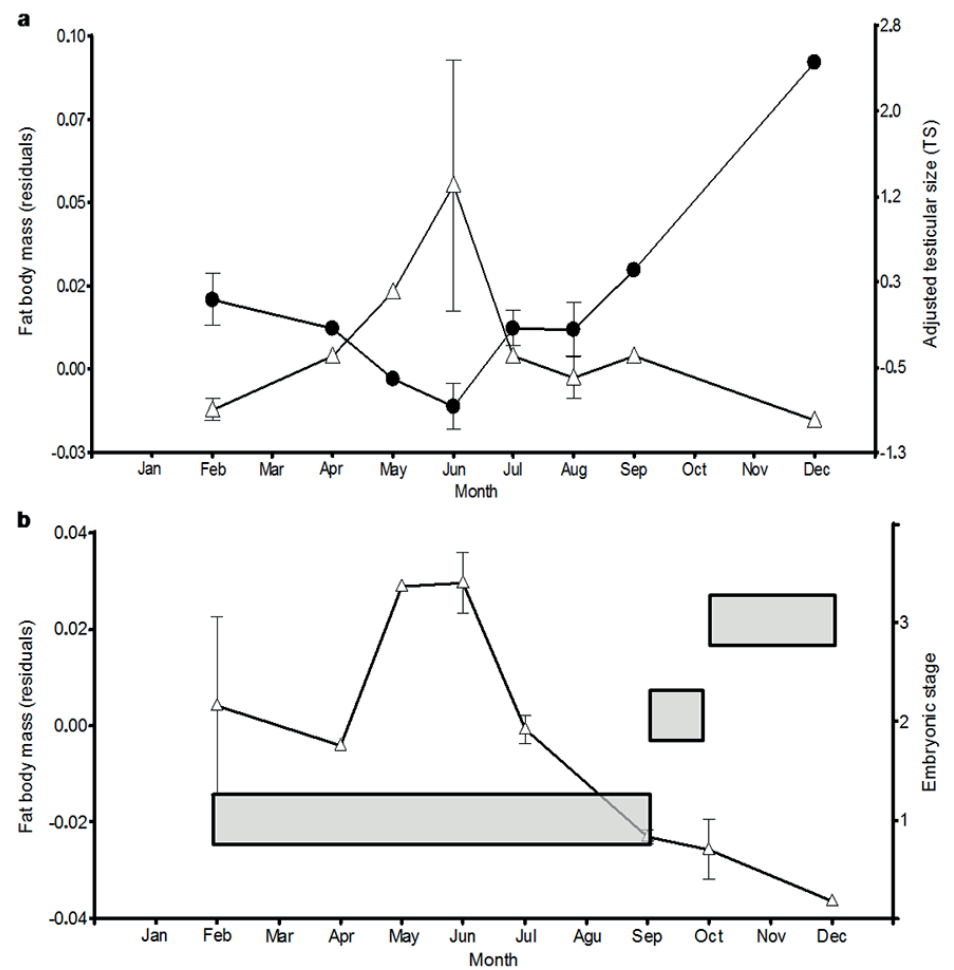

Figure 6 - Fat body annual cycle of Mabuya dorsivittata adults. (a) Monthly means of the residuals obtained from the linear regressions between fat body mass and snout-vent length (triangles) and between means of testicular diameter and snout-vent length (solid circles). (b) Monthly of the means residuals of fat bodies (triangles) and embryonic stages: 1) initial, 2) medium, and 3) advanced. Vertical bars indicate 1 SE.

\section{DISCUSSION}

Mabuya dorsivittata from the wet environments of Corrientes exhibited associated, seasonal and annual reproductive cycles in both males and females. Females displayed a long gestation period, showing embryos with an early stage of development in mid-summer (February), and an advanced stage in late spring (December), indicating that births occur during late spring (December) after 11 months of gestation. The gestation time estimated for M. dorsivittata from the Wet Chaco biome is coincident with the time span documented for congeners from other biomes of Brazil and Colombia (Amazon, Caatinga, Atlantic Forest and Cerrado biomes, Brazil, 9-12 months; Vitt and Blackburn 1983, 1991, Vrcibradic and Rocha 1998, Rocha and Vrcibradic 1999, Ribeiro et al. 2015, and tropical wet forest, Colombia, RamírezPinilla et al. 2002). Males showed the maximum spermatogenic activity in late spring (December), after females have completed gestation, and are ready to mate and begin a new reproductive cycle.

The testicular cycle of $M$. dorsivittata in the Corrientes population varied positively with the photoperiod, while the female reproductive cycle was linked to temperature and historical rainfall. However, the male reproductive cycle in tropical species of Mabuya is more strongly associated with the female cycle rather than environmental factors; the maximum spermatogenic activity usually coincides with birth and ovulation times (Rocha 
and Vrcibradic 1999) as is seen in M. dorsivittata from Corrientes. Furthermore, the reproductive cycles of females in Mabuya are probably more dependent on the rainfall regime, as suggested by the observation that births occur during the transition period between the dry and wet seasons (see Vrcibradic and Rocha 2011), when there is greater availability of prey, which probably increases the offspring survival (Vitt and Blackburn 1991, Vrcibradic and Rocha 1998, Ramírez-Pinilla et al. 2009). Births in M. dorsivittata from the Wet Chaco region occur from late spring seemingly to early summer (December and January; Table I), while in the population in the Espinal biome from Córdoba (Argentina) births occur only during the summer (January and February; Aun et al. 2011), when temperatures and rainfall are high in both biomes.

The comparative analysis reveals that there is a delay in parturition as latitude increases, shifting from early spring to early summer. In tropical populations, the availability of food for hatchlings could determine the time of births (Vitt and Blackburn 1983); nevertheless, in the more southern populations the environmental temperature could play a more important role, and births in summer probably occur as a result of differences in the opportunities of females to maintain optimum temperature for embryonic development through thermoregulation (Wapstra and Swain 2001, Aun et al. 2011). Temperature can also indirectly affect the timing of birth, since increases in the diversity and abundance of arthropods in the summer at more southerly sites could be associated with the increase in temperature (Kearns and Stevenson 2012). Nevertheless, maximum accumulation of lipids in fat bodies occurs in late autumn (June) in M. dorsivittata from the Wet Chaco region, when temperature and rainfall drop; thus, availability of food does not seem to be a limitation for this region.

Likewise, a decrease in the fat-body mass during the reproductive season has been registered in numerous squamate species (Rocha 1992, Wiederhecker et al. 2002, Ramírez-Bautista et al. 2009), as exemplified by $M$. dorsivittata from Corrientes. In our study, an inverse relationship was observed between fat-body mass and spermatogenic activity in males, and between fat-body mass and embryonic development in females, indicating the high energetic cost entailed in reproduction in both sexes. In females, lipid resources can be used either in the vitellogenic stage or during embryonic development or in both (Hahn and Tinkle 1965, Guillette and Casas-Andreu 1981, Vitt and Blackburn 1983). Thus, in M. dorsivittata from Corrientes, females store lipids in the initial phase of gestation, while lipids deposited in the fat bodies decrease in the medium and advanced stages of embryonic development, similar to the congeneric pattern (Vitt and Blackburn 1983, Ramírez-Pinilla et al 2002), suggesting that lipid storage is responsible for the maintenance of the females during gestation, and even more so during the middle and final stages of embryo growth (Ramírez-Pinilla et al. 2002). However, during the pre-ovulatory phase (follicular growth) a large mobilization of lipids would not be necessary to produce microlecithal oocytes, hence the cycle of fat-body mass in Mabuya species seems to be strongly associated with placentotrophy (Gómez and Ramírez-Pinilla 2004). In this sense, the small diameter of oocytes at ovulation in M. dorsivittata, as throughout the clade Mabuya (Ramírez-Pinilla 2014), indicates the microlecithal character. The small size of the eggs results from a vitellogenic phase reduction as a consequence of the placental matrotrophy present in this group (Ramírez-Pinilla 2010, 2014).

Biotic and abiotic factors are involved in the evolution of the optimal litter size, and therefore it is possible to find differences in the reproductive potential among species or among populations of the same species (Table I), because of the variation in the selective forces on the populations throughout 


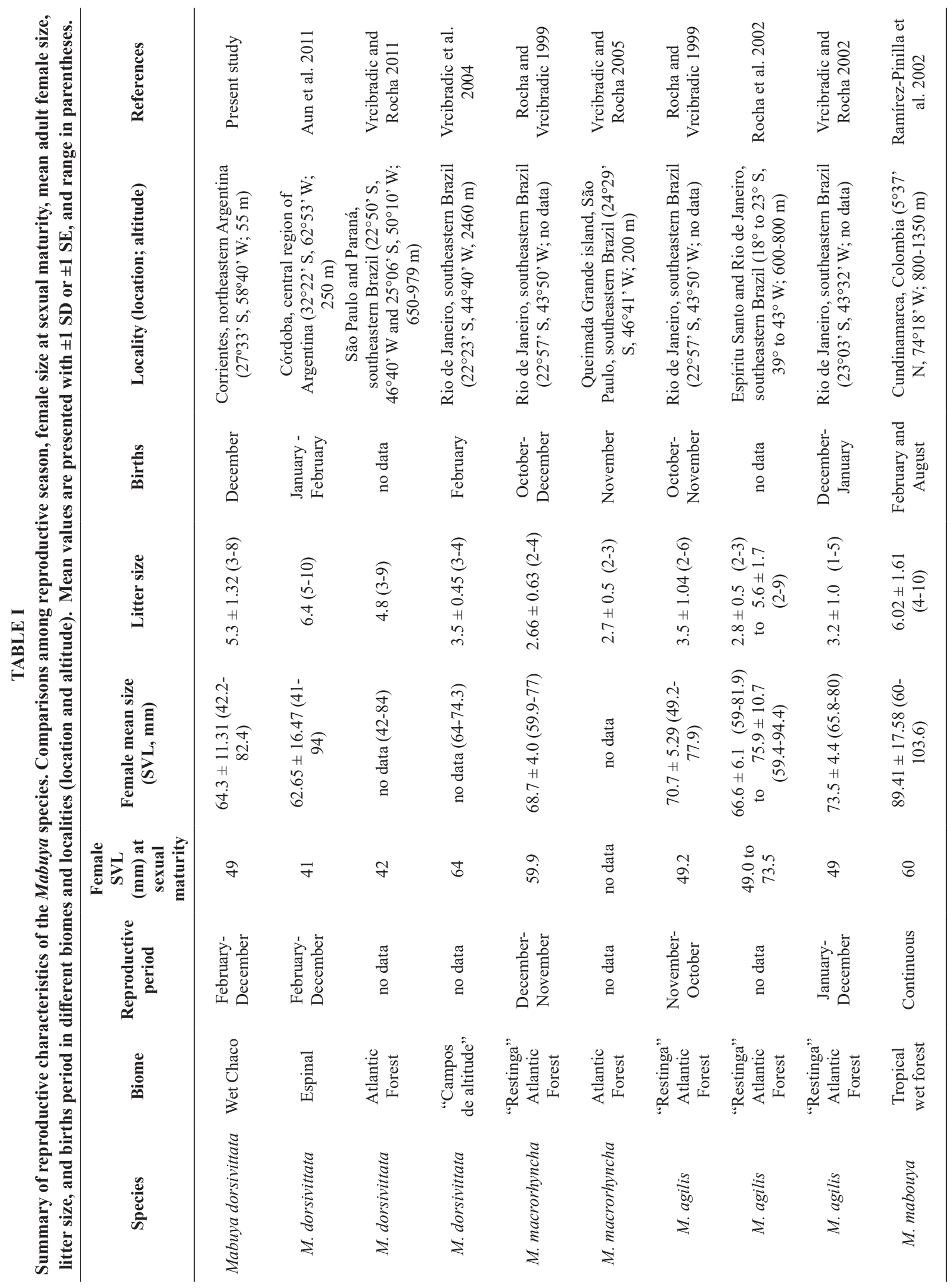




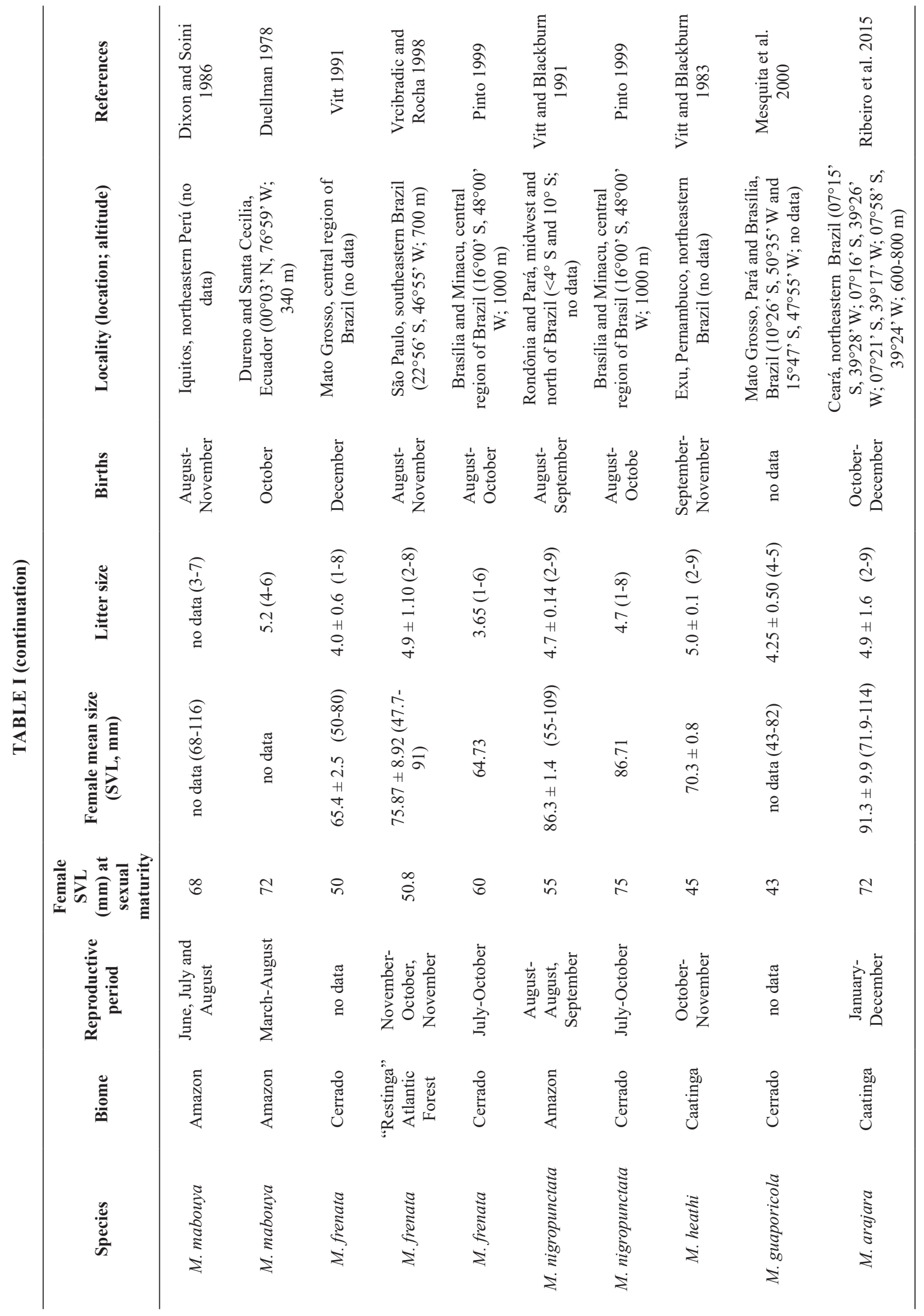


its distribution (Fitch 1985). Litter size of $M$. dorsivittata suggests a latitudinal and an altitudinal gradient; the populations at lower latitudes, in southeastern Brazil, showed the lowest fecundity ( $22^{\circ} 23^{\prime} \mathrm{S}, 44^{\circ} 40^{\prime} \mathrm{W}$, altitude $2460 \mathrm{~m}$; Vrcibradic et al. 2004; 22 $50^{\prime} \mathrm{S}, 46^{\circ} 40^{\prime} \mathrm{W}$ and $25^{\circ} 06^{\prime} \mathrm{S}$, $50^{\circ} 10^{\prime} \mathrm{W}$, altitudes $650-979 \mathrm{~m}$; Vrcibradic and Rocha 2011), whereas the southernmost population (Espinal biome from Córdoba, Argentina) showed the highest registered mean fecundity $\left(32^{\circ} 22^{\prime} \mathrm{S}\right.$, $62^{\circ} 53^{\prime} \mathrm{W}$, altitude $250 \mathrm{~m}$; Aun et al. 2011; Table I). Mabuya dorsivittata from the Wet Chaco population exhibited a moderate litter size $\left(27^{\circ} 33^{\prime}\right.$ S, 58 $40^{\prime}$ 'W, altitude $55 \mathrm{~m}$; present study). Such differences in litter size could be explained by a difference in the female maximum SVL attained in the different populations (Table I), because females from the Espinal biome show larger maximum SVL (Aun et al. 2011) than those in the "campos de altitude" (montane fields in Atlantic Forest) biome in southeastern Brazil (Vrcibradic et al. 2004).

In many taxa, litter or clutch size increases with female body size (Andersson 1994), because larger females have more space for a larger number of offspring or eggs (Andersson 1994, Shine 1988); therefore, female-biased sexual size dimorphism and higher interlimb length in M. dorsivittata females from the Wet Chaco biome could be attributed to fecundity selection (Shine 1988). On the other hand, allometric growth of head length of males could be explained by sexual selection for an advantageous characteristic that improves the chance of success in male-male combat (Vitt and Cooper 1985, Anderson and Vitt 1990, Andersson 1994). Larger body size in females and the proportionally larger head size in males have been observed in other species of the genus Mabuya (sensu stricto; Vitt and Blackburn 1983, Vrcibradic and Rocha 1998, Rocha and Vrcibradic 1999, Ramírez-Pinilla et al. 2002, Ribeiro et al. 2015) and this suggests that the sexual dimorphism pattern found in $M$. dorsivittata from Corrientes could be a plesiomorphic character for the genus.

The anti-predatory (voluntary) behavior of caudal autotomy can also be different between males and females (Bateman and Fleming 2009, Cromie and Chapple 2013). For example, in Mabuya heathi it has been reported that males lose their tails more frequently than females (Vitt 1981). However, although $70 \%$ of specimens of $M$. dorsivittata from Corrientes showed caudal autotomy, there was no significant difference between the sexes, regardless of SVL and body mass of individuals. This high frequency in the caudal autotomy is shared with other members of the genus; hence, it is likely that the high frequency of tail loss is a result of the evolutionary history of the group (see Van Sluys et al. 2002).

The reproductive patterns of most squamates that inhabit the Wet Chaco region remain unknown, but interestingly, the few squamate species studied to date (Tropidurus catalanensis-formerly $T$. torquatus, Ortiz et al. 2014; Kentropyx viridistriga, Ortiz et al. 2016; Ophiodes intermedius, Ortiz et al. 2017; Amphisbaena mertensii, Aguirre et al. 2017) show a broad spectrum of reproductive styles including continuous, seasonal, associated, and asynchronous cycles, different reproductive modes with different embryonic nutrition strategies, single and multiple clutches, and sperm storage in males. In particular, the reproductive pattern of $M$. dorsivittata from the Wet Chaco region resembles the general pattern of the genus: seasonal reproduction and an associated reproductive cycle, an extended period of gestation, seasonal lipid accumulation and sexual dimorphism. However, it differs in some particular aspects such as the timing of parturition, litter size, and minimum size at sexual maturity, indicating adjustments to local environmental pressures. Usually, the comparative studies showing geographical variation in lifehistory traits between populations attributes such variations to genetic differences or plastic 
responses to different environmental conditions. Future studies under controlled laboratory experiments or using reciprocal transplants are necessary to verify the relative contributions of genotype and environment, and thereby enhance our understanding of geographical life-history patterns.

\section{ACKNOWLEDGMENTS}

We thank J. L. Acosta, E. Etchepare, J. Valdés, R. Aguirre, D. Aguiar, S. Palomas, A. C. Falcione and M. R. Ingaramo for their assistance during the field work. This study was supported by a research grant from the Secretaría General de Ciencia y Técnica (SGCyT) and Universidad Nacional del Nordeste (UNNE) (P16F-011), and the Consejo Nacional de Investigaciones Científicas y Técnicas (CONICET) (PIP 11220120100676). We are grateful to John D. Krenz and two anonymous reviewers for their critical reviews and their insightful comments of the manuscript. We also thank the Dirección de Fauna of Corrientes for the collecting permits.

\section{AUTHOR CONTRIBUTIONS}

Martín Ortiz, Jorgelina M. Boretto and Nora R. Ibargüengoytía conceived the article; Martín Ortiz collected data and performed the analyses with contributions of Jorgelina M. Boretto and Nora R. Ibargüengoytía. Martín Ortiz, Jorgelina M. Boretto and Nora R. Ibargüengoytía wrote the manuscript.

\section{REFERENCES}

ADOLPH S AND PORTER WP. 1993. Temperature, activity, and lizard life histories. Am Nat 142: 273-295.

AGUIRRE FD, ORTIZ MA AND HERNANDO AB. 2017. Testicular cycle of Amphisbaena mertensii Strauch, 1881 (Squamata: Amphisbaenidae) in northeastern Argentina. Herpetol Notes 10: 141-145.

ALVAREZ BB, AGUIRRE RH, CÉSPEDEZ JA, HERNANDO AB, TEDESCO ME AND ORFEO O. 2002. Atlas de Anfibios y Reptiles de las provincias de Corrientes, Chaco y Formosa (Argentina) I (Anuros,
Cecílidos, Saurios, Amphisbénidos y Serpientes). Corrientes: EUDENE, $160 \mathrm{p}$.

ANDERSON RA AND VITT LJ. 1990. Sexual selection versus alternative causes of sexual dimorphism in teiid lizards. Oecologia 84: 145-157.

ANDERSSON M. 1994. Sexual selection. New Jersey: Princeton University Press, 599 p.

AUN L, BORGHI D AND MARTORI R. 2011. Reproducción y dieta de una población de Mabuya dorsivittata (Squamata, Scincidae) en Córdoba, Argentina. Rev Peru Biol 18: 19-25.

BATEMAN PW AND FLEMING PA. 2009. To cut a long tail short: a review of lizard caudal autotomy studies carried out over the last 20 years. J Zool 277: 1-14.

BLACKBURN DG. 1992. Convergent evolution of viviparity, matrotrophy, and specializations for fetal nutrition in Reptiles and other vertebrates. Am Zool 32: 313-321.

BLACKBURN DG AND VITT LJ. 1992. Reproduction in viviparous South American lizards of the genus Mabuya. In: Hamlett WC (Ed), Reproductive Biology of South America Vertebrates, New York: Springer-Verlag, p. 150164.

BLACKBURN DG AND VITT LJ. 2002. Specialization of the chorioallantoic placenta in the Brazilian scincid lizard Mabuya heathi a new placental morphotype for reptiles. J Morphol 254: 121-131.

BORETTO JM AND IBARGÜENGOYTÍA NR. 2009. Phymaturus of Patagonia, Argentina: Reproductive biology of Phymaturus zapalensis (Liolaemidae) and comparison of sexual dimorphism within the genus. J Herpetol 43: 96-104.

BORETTO JM, IBARGÜENGOYTÍA NR, ACOSTA JC, BLANCO GM, VILLAVICENCIO J AND MARINERO JA. 2007. Reproductive biology and sexual dimorphism of a high-altitude population of the viviparous lizard Phymaturus punae from the Andes in Argentina. Amphibreptil 28: 427-432.

BRUNIARD E. 1997. Atlas geográfico de la provincia de Corrientes. Tomo I: El medio natural, Chaco: Geográfica: Revista del Instituto de Geografía, Facultad de Humanidades, Universidad Nacional del Nordeste, Argentina.

CABRERA AL. 1976. Enciclopedia Argentina de agricultura y jardinería, Tomo II, Fascículo 1: regiones fitogeográficas argentinas, Buenos Aires: ACME, 85 p.

CABRERA AL AND WILLINK A. 1973. Biogeografía de América Latina. Monografía 13. Washington: Serie de Biología, OEA, USA, 120 p.

CARNEVALI R. 1994. Fitogeografía de la provincia de Corrientes. Cartas, escalas 1:500.000 y 1:1.000.000, Corrientes: Gobierno de la provincia de Corrientes, INTA, Argentina, $324 \mathrm{p}$. 
CEI JM. 1993. Reptiles del noroeste, nordeste y este de la Argentina. Herpetofauna de las selvas subtropicales, Puna y Pampas, Monografía XIV, Torino: Museo Regionale di Scienze Naturali, Italia, 949 p.

CLOSE B ET AL. 1997. Recommendations for euthanasia of experimental animals: Part 2. DGXT of the European Commission. Lab Anim 31: 1-32.

CROMIE GL AND CHAPPLE DG. 2013. Is partial tail loss the key to a complete understanding of caudal autotomy? Austral Ecology 38: 452-455.

DIXON JR AND SOINI P. 1986. The Reptiles of the Upper Amazon Basin, Iquitos Region, Peru. Wisconsin: Milwawkee Publ Mus, Inc, USA, 154 p.

DUELLMAN WE. 1978. The biology of an equatorial herpetofauna in Amazonian Ecuador. Miscellaneous publication Museum Natural History University of Kansas, Lawrence, Kansas 65: 1-352.

DUNHAM AE, MILES DB AND REZNICK DN. 1988. Life History Patterns in Squamate Reptiles. In: Gans C and Huey RB (Eds), Biology of the Reptilia, Vol. 16. Ecology B: defense and life history, New York: Alan R. Liss, Inc., New York, USA, p. 441-522.

FITCH HS. 1985. Variation in clutch and litter size in New World reptiles. University of Kansas Museum of Natural History, Miscellaneous Publication 76: 1-76.

GINZBURG R AND ADÁMOLI J. 2006. Situación ambiental en el Chaco Húmedo. In: Brown A, Martinez Ortiz U, Acerbi M and Corcuera J (Eds), La Situación Ambiental Argentina 2005, Buenos Aires: Fundación Vida Silvestre Argentina, Argentina, p. 103-113.

GÓMEZ D AND RAMÍREZ-PINILLA M. 2004. Ovarian histology of the placentotrophic Mabuya mabouya (Squamata, Scincidae). J Morphol 259: 90-105.

GRIBBINS KM. 2011. Reptilian spermatogenesis. A histological and ultrastructural perspective. Landes Bioscience 1: 250-269.

GUILLETTE JR LJ AND CASAS-ANDREU G. 1981. Seasonal variation in fat body weights of the Mexican high elevation lizard Sceloporus grammicus microlepidotus. J Herpetol 15: 366-377.

HAHN WE AND TINKLE DW. 1965. Fat body cycling and experimental evidence for its adaptive significance to ovarian follicle development in the lizard Uta stansburiana. J Exp Zool 158: 79-86.

HEDGES SB AND CONN CE. 2012. A new skink fauna from Caribbean islands (Squamata, Mabuyidae, Mabuyinae). Zootaxa 3288: 1-244.

HUMASON GL. 1979. Animal tissue techniques, $4^{\text {th }}$ ed., San Francisco: Freeman \& Company, $661 \mathrm{p}$.

IBARGÜENGOYTÍA NR AND CUSSAC VE. 1998. Reproduction of the viviparous lizards Liolaemus elongatus in the highlands of southern South America: plastic cycles in response to climate? Herpetol J 8: 99-105.
JEREZ A. 2012. Características estructurales del esqueleto en Mabuya sp. (Squamata: Scincidae): una comparación con escíncidos africanos. Actual Biol 34: 207-223.

JEREZ A AND RAMÍREZ-PINILLA MP. 2001. The allantoplacenta of Mabuya mabouya (Sauria, Scincidae). J Morphol 249: 132-146.

JEREZ A AND RAMÍREZ-PINILLA MP. 2003. Morphogenesis of extraembryonic membranes and placentation in Mabuya mabouya (Squamata, Scincidae). J Morphol 258: 158-178.

JI X, LIN CX, LIN LH, QIU QB AND DU Y. 2007. Evolution of viviparity in warm-climate lizards: an experimental test of the maternal manipulation hypothesis. J Evol Biol 20: 1037-1045.

KEARNS P AND STEVENSON RD. 2012. The effect of decreasing temperature on arthropod diversity and abundance in horse dung decomposition communities of southeastern Massachusetts. Psyche 2012: 1-12.

LEAL F AND RAMÍREZ-PINILLA MP. 2008. Morphological variation in the allantoplacenta within the genus Mabuya (Squamata: Scincidae). Anat Rec 291: 1124-1139.

LEYTON VC, MIRANDA EA AND BUSTOS-OBREGÓN E. 1980. Gestational chronology in the viviparous lizard Liolaemus gravenhorsti (Gray) with remarks on ovarian and reproductive activity. Arch Biol 91: 347-361.

MAUSFELD P, SCHMITZ A, BÖHME W, MISOF B, VRCIBRADIC D AND ROCHA CFD. 2002. Phylogenetic affinities of Mabuya atlantica Schmidt, 1945, endemic of the Atlantic Ocean Archipelago of Fernando de Noronha (Brazil): necessity of partition of genus Mabuya Fitzinger, 1826 (Scincidae: Lygosominae). Zool Anz 241: 281-293.

MAYHEW WW AND WRIGHT S. 1970. Seasonal changes in testicular histology of three species of the lizard genus Uma. J Morphol 130: 163-186.

MESQUITA DO, PÉREZ JR AK, VEIRA GHC AND COLLI GR. 2000. Mabuya guaporicola (Calango-Liso). Natural History. Herpetol Review 31: 240-241.

MIRALLES A AND CARRANZA S. 2010. Systematics and biogeography of the Neotropical genus Mabuya, with special emphasis on the Amazonian skink Mabuya nigropunctata (Reptilia, Scincidae). Mol Phylogenet Evol 54: 857-869.

NÚÑEZ K. 2012. La herpetofauna de un fragmento de Bosque Atlántico en el Departamento de Itapúa, Paraguay. Bol Asoc Herpetol Esp 23: 47-52.

OLSSON M, SHINE R, WAPSTRA E, UJVARI B AND MADSEN T. 2002. Sexual dimorphism in lizard body shape: the roles of sexual selection and fecundity selection. Evolution 56: 1538-1542.

ORTIZ MA, BORETTO JM AND IBARGÜENGOYTÍA NR. 2016. Reproductive biology of the southernmost Kentropyx lizard from the Wet Chaco of Corrientes, Argentina. Herpetol J 26: 119-130. 
ORTIZ MA, BORETTO JM AND IBARGÜENGOYTÍA NR. 2017. How does a viviparous semifossorial lizard reproduce? Ophiodes intermedius (Squamata: Anguidae) from subtropical climate in the Wet Chaco region of Argentina. Zoology 121: 35-43.

ORTIZ MA, BORETTO JM, PIANTONI C, ÁLVAREZ BB AND IBARGÜENGOYTÍA NR. 2014. Reproductive biology of the Amazon Lava Lizard (Tropidurus torquatus) from the Wet Chaco of Corrientes (Argentina): congeneric comparisons of ecotypic and interspecific variations. Can J Zool 92: 643-655.

PINTO MGM. 1999. Ecologia das espécies de lagartos simpátricos Mabuya nigropunctata e Mabuya frenata (Scincidae), no Cerrado de Brasília e Serra da Mesa (GO), 104 p. Dissertação de Mestrado, Universidade de Brasília, Instituto de Ciências Biológicas, Departamento de Ecologia, Brasília, Brazil. (Unpublished).

PYRON RA, BURBRINK FT AND WIENS JJ. 2013. A phylogeny and revised classification of Squamata, including 4161 species of lizards and snakes. BMC Evol Biol 13: 93.

RADDER RS. 2006. An overview of geographic variation in the life history traits of the tropical agamid lizard, Calotes versicolor. Curr Sci 91: 1354-1363.

RAMÍREZ-BAUTISTA A, BARBA-TORRES J AND VITT LJ. 1998. Reproductive cycle and brood size of Eumeces lynxe from Pinal de Amoles, Queretero, México. J Herpetol 32: $18-24$.

RAMÍREZ-BAUTISTA A, HERNÁNDEZ-RAMOS D, ROJAS-MARTÍNEZ A AND MARSHALL JC. 2009. Fat bodies and liver mass cycles in Sceloporus grammicus (Squamata: Phrynosomatidae) from southern Hidalgo, México. Herpetol Conserv Biol 4: 164-170.

RAMÍREZ-BAUTISTA A, RAMOS-FLORES O AND SITES JRJW. 2002. Reproductive cycle of the spiny lizard Sceloporus jarrovii (Sauria: Phrynosomatidae) from North-Central México. J Herpetol 36: 225-233.

RAMÍREZ-BAUTISTA A AND VITT LJ. 1997. Reproduction in the lizard Anolis nebulosus (Polychrotidae) from the Pacific coast of Mexico. Herpetologica 53: 423-431.

RAMÍREZ-PINILLA MP. 2010. Matrotrofía en reptiles escamados. In: Hernández Gallegos O, Méndez de la Cruz FR and Méndez Sánchez JF (Eds), Reproducción en reptiles: morfología, ecología y reproducción, Toluca: Universidad Autónoma del Estado de México, México, p. 109-136.

RAMÍREZ-PINILLA MP. 2014. Biología reproductiva y placentotrofía en lagartijas del género Mabuya. Rev Acad Colomb Cienc 38: 106-117.

RAMÍREZ-PINILLA MP, CALDERÓN-ESPINOSA ML, FLORES-VILLELA O, MUÑOZ-ALONZO A AND MÉNDEZ DE LA CRUZ FR. 2009. Reproductive activity of three sympatric viviparous lizards at Omiltemi,
Guerrero, Sierra Madre del Sur, México. J Herpetol 43: 409-420.

RAMÍREZ-PINILLA MP, SERRANO VH AND GALEANO JC. 2002. Annual reproductive activity of Mabuya mabouya (Squamata, Scincidae). J Herpetol 36: 667-677.

RIBEIRO SC, TELES DA, MESQUITA DO, ALMEIDA WO, DOS ANJOS LA AND GUARNIERI MC. 2015. Ecology of the skink, Mabuya arajara Rebouças-Spieker, 1981, in the Araripe Plateau, northeastern Brazil. J Herpetol 49: 237-244.

ROCHA CFD. 1992. Reproductive and fat body cycles of the tropical sand lizard (Liolaemus lutzae) of southeastern Brazil. J Herpetol 26: 17-23.

ROCHA CFD AND VRCIBRADIC D. 1999. Reproductive traits of two sympatric viviparous skinks (Mabuya macrorhyncha and Mabuya agilis) in a Brazilian resting habitat. Herpetol J 9: 43-53.

RODRÍGUEZ-DÍAZ T AND BRAÑA F. 2011. Shift in thermal preferences of female oviparous common lizards during egg retention: insights into the evolution of reptilian viviparity. Evol Biol 38: 352-359.

SEIGEL RA AND FORD NB. 2001. Phenotypic plasticity in reproductive traits: geographical variation in plasticity in a viviparous snake. Funct Ecol 15: 36-42.

SHINE R. 1985. The evolution of viviparity in reptiles: an ecological analysis. In: Gans C and Billett F (Eds), Biology of the Reptilia, New York: J Wiley \& Sons, New York, USA, p. 605-694.

SHINE R. 1988. The evolution of large body size in females: a critique of Darwin's "fecundity advantage" model. Am Nat 131: 124-131.

VAN SLUYS M, MENDES HM, ASSIS VB AND KIEFER MC. 2002. Reproduction of Tropidurus montanus Rodrigues, 1987 (Tropiduridae) a lizard from a seasonal habitat of southeastern Brazil, and a comparison with other Tropidurus species. Herpetol J 12: 89-97.

VITT LJ. 1981. Tail autotomy and regeneration in the tropical skink, Mabuya heathi. J Herpetol 15: 454-457.

VITT LJ. 1991. An introduction to the ecology of cerrado lizards. J Herpetol 25: 79-90.

VITT LJ AND BLACKBURN DG. 1983. Reproduction in the lizard Mabuya heathi (Scincidae): a commentary on viviparity in New World Mabuya. Can J Zool 61: 27982806.

VITT LJ AND BLACKBURN DG. 1991. Ecology and life history of the viviparous lizard Mabuya bistriata (Scincidae) in the Brazilian Amazonia. Copeia 1991: 916927.

VITT LJ AND COOPER JRWE. 1985. The evolution of sexual dimorphism in the skink Eumeces laticeps: An example of sexual selection. Can J Zool 63: 995-1002.

VRCIBRADIC D AND ROCHA CFD. 1998. Reproductive cycle and life-history traits of the viviparous skink Mabuya frenata in southeastern Brazil. Copeia 1998: 612-619. 
VRCIBRADIC D AND ROCHA CFD. 2002. Ecology of Mabuya agilis (Raddi) (Lacertilia, Scincidae) at the restinga of Grumari, Rio de Janeiro, southeastern Brazil. Rev Bras Zool 19: 19-29.

VRCIBRADIC D AND ROCHA CFD. 2005. Observations on the natural history of the lizard Mabuya macrorhyncha Hoge (Scincidae) in Queimada Grande Island, São Paulo, Brazil. Rev Bras Zool 22: 1185-1190.

VRCIBRADIC D AND ROCHA CFD. 2011. An overview of female reproductive traits in South American Mabuya (Squamata, Scincidae), with emphasis on brood size and its correlates. J Nat Hist 45: 813-825.

VRCIBRADIC D, ROCHA CFD, MENEZES VA AND ARIANI CV. 2004. Geographic distribution. Mabuya dorsivittata. Herpetol Rev 35: 409.

WAPSTRA E AND SWAIN R. 2001. Geographic and annual variation in life history traits in small Australian skink. J Herpetol 35: 194-203.

WEBB JK, SHINE R AND CHRISTIAN KA. 2006. The adaptive significance of reptilian viviparity in the tropics: testing the maternal manipulation hypothesis. Evolution 60: 115-122.

WHITING A S, SITES, JRJW, PELLEGRINO KCM AND RODRIGUES MT. 2006. Comparing alignment methods for inferring the history of the new world lizard genus Mabuya (Squamata: Scincidae). Mol Phylogenet Evol 38: 719-730.

WIEDERHECKER HC, PINTO ACS AND COLLI GR. 2002. Reproductive ecology of Tropidurus torquatus (Squamata: Tropiduridae) in the highly seasonal Cerrado biome of central Brazil. J Herpetol 36: 82-91.

WILLIAMS J AND KACOLIRIS F. 2011. Squamata, Scincidae, Mabuya dorsivittata (Cope, 1862): Distribution extension in Buenos Aires province, Argentina. Check List 7: 388.

ZENG ZG, ZHAO JM AND SUN BJ. 2013. Life history variation among geographically close populations of the toad-headed lizard (Phrynocephalus przewalskii): Exploring environmental and physiological associations. Acta Oecol 51: 28-33. 